\section{Kastamonu Eğitim Dergisi Kastamonu Education Journal}

Mart 2019 Cilt:27 Sayı:2

kefdergi.kastamonu.edu.tr
Başvuru Tarihi/Received: 12.01 .2018

Kabul Tarihi/Accepted: 06.08.2018 DOI: $10.24106 /$ kefdergi.2549

\title{
Turizm ve Otelcilik Meslek Yüksekokullarında Öğrenim Gören Öğrencilerin Eğitim-Öğretim Hizmet Kalitesine İlişkin Görüşlerinin Belirlenmesi (Türkiye Örneği) ${ }^{1}$
}

\section{Determining The Views of Vocational School of Tourism and Hotel Management Students on The Quality of Education (The Case of Turkey)}

\section{Öz}

\author{
Atınç OLCAY'2 Eşref AY ${ }^{3}$
}

Bu araştırma Türkiye'deki Turizm ve Otelcilik Meslek Yüksekokulları'nda öğrenim gören öğrencilerin eğitim-öğretim hizmet kalitesine ilişkin görüşlerinin belirlenmesi amacıyla yapılmıştı. Bu amaçla oluşturulan anket formu araştırma evrenini temsil eden 850 öğrenciye uygulanmıştr. Elde elden veriler SPSS 23.0 paket programıyla analiz edilmiştir. Araştırma sonucunda, Türkiye'deki Turizm ve Otelcilik Meslek Yüksekokulları'nda öğrenim gören öğrencilerin eğitim-öğretim hizmet kalitesine yönelik görüşlerinin genel olarak olumlu yönde olduğu, okulların öğrencilerin sosyalleşebilecekleri ortak alanlara, bilişim-teknoloji imkânlarına sahip olmaları ve bu imkânlardan öğrencilerin kolaylıkla yararlanabilmeleri konularında da öğrencilerin ağırlıklı olarak kararsız görüş bildirdikleri tespit edilmiştir. Bunun yanında öğrencilerin eğitim-öğretim hizmet kalitesine yönelik görüşlerinin ölçekte belirlenen faktörlere ve okullara göre farklılaştğ̆ı da tespit edilmiştir. Ayrıca öğrencilerin bazı demografik verilerine göre eğitim-öğretim hizmet kalitesine ilişkin görüşlerinde farklılaşma olduğu istatistiki olarak ortaya konulmuştur.

Anahtar Kelimeler: Eğitim-öğretim hizmet kalitesi, turizm eğitimi, meslek yüksekokulu

\section{Abstract}

This study was conducted to determine the views of vocational school of tourism and hotel management students on the quality of education and training. The survey form created for this purpose was applied to 850 students that fit the study subject. The data obtained was analyzed by using the SPSS 23.0 program. The study concluded that vocational school of tourism and hotel management students have a positive overall outlook on the quality of education and training, and they are mainly undecided on whether they have the common areas to socialize or whether they have information-technology facilities that are easily available to them. Besides, according to the some demographic and descriptive data of students, it is analyzed as differentiation statistics in views on the quality of education and training

Keywords: Service quality of education, tourism education, vocational school

\footnotetext{
1. Bu makale, birinci yazarın danışmanlığında ikinci yazar tarafindan hazırlanmış olan yüksek lisans tezinden üretilmiştir. Araştırma sonuçlarının bir bölümü 11-14 Mayıs 2017 tarihlerinde düzenlenen Al-Farabi 1.Uluslararası Sosyal Bilimler Kongresinde bildiri olarak sunulmuştur.

2. Gaziantep University Tourism Faculty, Gaziantep, Türkiye; https://orcid.org/0000-0003-0407-5467

3. Anadolu University Department of Tourism Management, Eskişehir, Turkey; https://orcid.org/0000-0003-4092-642

Atıf / Citation: Olcay, A., \& Ay, E. (2019). Turizm ve otelcilik meslek yüksekokullarında öğrenim gören öğrencilerin eğitim-öğretim hizmet kalitesine ilişkin görüşlerinin belirlenmesi (Türkiye örneği).Kastamonu Education Journal, 27(2), 453-466. doi:10.24106/kefdergi.2549
} 


\section{Extended Summary}

Introduction: The main problem of tourism within the service sector is the low quality of service (Altan, Atan ve Ediz, 2003: 2). Quality service is carried out with qualified personnel. Therefore, the basic element of the service industry is human. The provision of qualified manpower depends on the provision of quality and effective tourism education and training (Ünlüönen, 2000: 218). The provision of the quality of service required by the understanding of contemporary tourism depends to a large extent on the quality of vocational and technical training of the workforce employed in the sector (Christou, 1999: 683; Alp, 1992: 47). In this context, the importance of the quality of the education provided by the education and training institutions that provide qualified work force to tourism sector emerges. This study was conducted to determine the views of vocational school of tourism and hotel management students on the quality of education and training.

Purpose and Importance: The main purpose of this research is to reveal students' views on the quality of education services in the Vocational Schools of Tourism and Hotel Management in Turkey and to contribute to the efforts to improve the quality of service of these schools. Growth in tourism has triggered competition between businesses operating in the sector, and the need for qualified human power has also been highlighted. The importance of secondary education and undergraduate education, which is the source of qualified human power in tourism, also arises here. In the light of the data obtained from this research, tourism vocational schools are important in terms of enabling them to review the quality of the education service they offer.

Method: The universe of this study is, in the 2015-2016 academic year 3987 students who studying at the vocational school of tourism and hotel management in Turkey. In this study, 1200 questionnaires were sent to schools for the students and 930 of them returned. Since 80 of the returned questionnaires were filled in incorrectly or incomplete, they were excluded from the evaluation and the analyses were conducted with a total of 850 questionnaires. In order to create a questionnaire form to be used, the studies (Parasuraman vd., 1988; Grönross, 1990; Cronin ve Taylor, 1994; Tsang ve Qu, 2000; Akbaba, 2006; Yılmaz, 2007) on the quality of service were examined and a questionnaire was prepared based on the "Faculty of Education - Student Satisfaction Scale" developed by Şahin (2009). The questionnaire consists of two parts. In the first part, there are 15 questions about the demographic and identification information of the participants. In the second part of the questionnaire, there are 33 questions prepared on a 7-point Likert scale to determine the opinions of the students in the Vocational Schools of Tourism and Hotel Management on the quality of education and training services. Participation expressions were scored from 7 to 1 , starting with "I am absolutely agree" in order to get a better understanding of the survey questions and to obtain more healthy results.

Findings: According to the results of one-way Anova analysis, it is seen that there is a significant difference between the opinions of students about the service quality and the schools they studied $(p<0,05)$. In terms of university variable, service quality, administrative service quality, support service received from the consultant, quality of service, quality of service-technology facilities, quality of service provided in schools and quality of service related to the programming of these courses and physical facilities have been determined to have a significant difference in perception of service quality $(p<0,05)$. Besides, according to the some demographic and descriptive data of students, it is analyzed as differentiation statistics in views on the quality of education and training.

\section{Conclusion and Discussion}

According to the results of the survey, it is seen that there is a meaningful difference in the quality of service received from the instructors according to the universities. It can be said that the students who participated in the survey gave positive opinions in general about the service they received from the instructors. Educational services provided by the teaching staff directly affect the total quality of the school. The level of perception of students' quality of managerial service differs according to the schools they are studying. In the areas where schools have the possibilities for students to have common activities, information and technology possibilities, and that students can easily benefit from these opportunities, the students have mainly expressed their hesitant opinions. When the physical location of the Vocational Schools of Tourism and Hotel Management in Turkey as a whole, it is seen that installed outside the university campus centers. It is considered that the organizational commitment towards the universities of the students who cannot benefit enough from the facilities provided by the central campus does not improve, which in turn affects the perceptions of the general service quality of the students. As a result of the analyzes made, it was determined that the opinions of the students about the quality of service did not differ according to the sections where they learned and the academic achievement averages. But it differs according to the sex of the students. Approximately four-thirds of the students who participated in the survey stated that they willingly preferred the program they were studying while the four-one part indicated that they unwillingly preferred the program. It has been determined that the students who think that they can find easy job after their graduation have higher perceptions of quality of education service. In particular, it can be said that physical facilities are the most important quality dimension for students. In this context, the importance of administrative service is also emerging. The main activities that school administrations can realize in order to improve the quality of education are the improvement of school physical facilities, the selection of academic staff, and the planning of course contents and course programs according to student needs. 


\section{Giriş}

Dış pazarlarda rekabet gücü en yüksek sektörlerden biri olan turizm, son yıllarda Türkiye'de de büyük bir hızla büyümüştür. Bu büyümeyle birlikte sektör, bazı temel sorunlarla karşı karşıya kalmıştı. Hizmet sektörü içinde yer alan turizmin başlıca sorunu, hizmet kalitesinin düşüklüğüdür (Altan, Atan ve Ediz, 2003: 2). Kaliteli hizmet nitelikli personel ile gerçekleşmektedir. Bu nedenle hizmet endüstrisinin temel öğesi "insan”dır. Nitelikli insan gücünün sağlanması da kaliteli ve etkin bir turizm eğitim ve öğretiminin verilmesine bağlıdır (Ünlüönen, 2000: 218). İnsana yatrım yapılmadan, fiziksel ve teknolojik donanımların, ekonomik gelişmelerin hizmet kalitesini artırmada ve geliştirmede etkili olması mümkün değildir (Seymen, 2002: 17).

Çağdaş turizm anlayışının gerektirdiği hizmet kalitesinin sunulması büyük ölçüde sektörde istihdam edilen işgücünün kaliteli mesleki ve teknik eğitim almasına bağlıdır (Christou, 1999: 683; Alp, 1992: 47). Milli eğitim sistemi kapsamında tarım, endüstri ve hizmet sektörleriyle birlikte her türlü mesleki ve teknik eğitim hizmetlerinin organizasyonu, planlanması, araştıılması, geliştirilmesi ve eşgüdümü ile denetim, yönetim ve öğretim etkinliklerinin tümü mesleki ve teknik eğitim olarak tanımlanmaktadır (Şahin ve Fındık, 2008: 65). Turizm olgusunu ve ekonomik hareketliliğini halka ve öğrenim gören öğrencilere öğreterek, turizm alanında kalifiye personel ve yönetici yetiştirilmesini amaçlayan çalışmaları ise turizm eğitimi olarak tanımlayabiliriz (Sezgin, 2001: 135; Hacıoğlu, 1992: 92). Turizm ve Otelcilik Meslek Liseleri, Meslek Yüksekokulları, Turizm Yüksekokulları ve Turizm Fakülteleri örgün eğitim kapsamında; çeşitli kurs ve sertifika programları da yaygın eğitim kapsamında turizm sektörüne nitelikli personel yetiştirmeyi amaçlamaktadırlar (Telbalkan, 2015: 17). Bu bağlamda turizm sektörüne nitelikli iş gücü yetiştiren eğitim-öğretim kurumlarının vermiş oldukları öğretimin kalitesinin de önemi ortaya çıkmaktadır.

Bu çalışmada, Türkiye'deki TOMYO'larda öğrenim gören öğrencilerin eğitim-öğretim hizmet kalitesine ilişkin görüşleri belirlenmeye çalışılmıştr.

\section{Kuramsal Çerçeve}

Amerikan Pazarlama Birliği (AMA) hizmet kavramını, sunulduğu anda tüketilen ve tüketici tatmini sağlayan soyut işler olarak tanımlamıştır (Çipil, 2004: 4). Hizmetin soyut bir kavram olması beraberinde hizmet kalitesinin de soyut bir kavram olması anlamına gelmektedir (Devebakan vd., 2003: 33). Hizmet kalitesine farklı bir açıdan bakan Parasuraman, Zeithaml ve Berry (1985), hizmet sürecinde tüketicinin hizmet kalitesi algısının, beklenen hizmet ile algılanan hizmet arasındaki farklılığın niteliğine bağlı olduğunu ortaya koymuşlardır.

Kaliteli eğitim; doğru zamanda, doğru kişilere, doğru eğitmenlerle, doğru yerlerde doğru eğitimin verilmesi ile gerçekleşebilir (Gülenç ve Talih, 2011: 264). Eğitimde kalite kavramını hem süreç hem de çıkt boyutlarında ele almak gerekir. Çıkt, belirlenen hedeflerin ve istenilen sonuçların elde edilmesini, süreç ise örgüt fonksiyonlarındaki basamakların belirlenen hedeflere yönelik etkili bir şekilde çalışmasını ifade etmektedir (Tezsürücü ve Bursalıoğlu, 2013: 102). Eğitimde kalitenin yükseltilebilmesi kaynakların yeterli düzeyde kullanılabilmesine, bilgi ve teknolojik gelişmelerin takip edilip bunların eğitime uyarlanmasına ve okul-öğrenci-aile-toplum arasında gerçekleşecek iş birliğine dayalıdır. Kaliteli eğitim ile diğer alanlara kalifiye işgücü sağlanması dolayısıyla diğer alanlarda da kalitenin arttırılması konusunda kaynak oluşturulmaktadır. Dolayısıyla eğitim-öğretim kalitesinin arttırılmasıyla, toplumsal gelişimin sağlanması doğrultusunda yaşamsal döngüye katkı sağlanabilmektedir (Tufan vd., 2009: 31).

\section{Türkiye'de Yükseköğretimde Turizm Eğitimi}

2016 yılı itibari ile Türkiye'de 955 meslek yüksekokulu bulunmaktadır (www.istatistik.yok.gov.tr, 10.04.2017). Bu okulların 167'sinde turizm eğitimi verilmeye devam edilmektedir (www.osym.gov.tr, 24.04.2017). Bu 167 okuldan yalnızca 9 tanesi sadece turizm eğitiminin verildiği TOMYO'lardır.

2016 yılı itibariyle 81 fakülte ve yüksekokulda turizm eğitimi verilmeye devam etmektedir. Bu fakültelerden 34'ü Turizm Fakültesi, 18'i Turizm ve Otel İşletmeciliği Yüksekokulu, 1'i Açıköğretim Fakültesi'dir. Geri kalan 28 okul ise bünyesinde turizm bölümleri bulunan diğer fakülte ve yüksekokullardır (www.osym.gov.tr, 24.04.2017). Türkiye'deki turizm lisansüstü program sayısı 2016 yılı itibariyle 34'ü yüksek lisans, 16'sı doktora olmak üzere toplam 50 adettir (YÖK, 2016).

\section{ilgili Araştırmalar}

Galeeva (2016) SERVQUAL ölçeğiyle Rusya'daki üniversitelerin yükseköğretim kalitesini ölçmeyi amaçlayan bir çaIışma yapmıştır. Garwe (2015) tarafindan yapılan çalışmada, Zimbabwe'de bulunan üniversitelerde eğitim hizmet kalitesinin artııımasında öğrenci düşüncelerinin etkisi ortaya konulmuştur. Halai (2012) Pakistan'daki özel üniversitelerin 
kamu üniversitelerine kıyasla eğitim kalitesi gelişimlerini incelemek amacıyla çalışma yapmıştır. Narang (2012), Hindistan'daki üniversite öğrencilerinin eğitimdeki algı ve beklentileri arasında anlamlı bir farklılık olduğunu tespit etmiștir. Petruzzellis ve diğerleri (2006) ve Joseph ve Joseph (1997) ayrı ayrı yaptıkları çalışmalarda, akademik ve fiziki yeterliliğe sahip üniversitelerin öğrenciler tarafindan kaliteli okullar olarak görüldüğü sonucuna ulaşmışlardır.

Olcay ve diğerlerinin (2016) yaptıkları çalışmada Gaziantep Üniversitesi TOMYO'da öğrenim gören öğrencilerin turizm programlarını popüler olmasından dolayı tercih ettiklerini tespit etmişlerdir. Olcay ve Düzgün (2015) Mesleki ve Teknik Anadolu Liseleri'nde turizm eğitimi almakta olan öğrencilerin bölümlerini sevdikleri ancak mezun olduktan sonra sektörde çalışma konusunda kararsız olduklarını belirlemişlerdir. Şahin (2009) Hacettepe Üniversitesi Illköğretim Bölümü’nde öğrenim gören öğrencilerin kendilerine sunulan eğitim hizmetlerine ilişkin memnuniyet düzeylerini belirlemeye yönelik çalışma yapmıştır. Çakır (2008) vakıf üniversiteleri üzerinde yaptı̆̆ı çalışmada öğrenci görüşlerinin, eğitim hizmet kalitesini ölçmede özellikle akademik personelin ders vermedeki başarısının güçlü ve zayıf yönlerini tespit etmede dikkate alınması gerektiğini ortaya koymuştur. Özçalık'ın (2007) yaptı̆ı̆ı çalışmamda, Çorum ili ve çevre ilçelerinde bulunan yükseköğretim kurumlarının fiziksel imkân ve özelliklerinin öğrenciler tarafindan algılanan hizmet kalitesinde önemli bir yer tuttuğu ortaya konulmuştur. Yılmaz ve diğerlerinin (2007) Eskişehir'de bulunan iki farklı üniversitenin Fen Fakültesi öğrencileri üzerine yaptıkları araştırma sonucunda, bu iki üniversite öğrencilerinin algılanan hizmet kalitesi skorlarında farklıık olduğu belirlenmiştir. Güzel'in (2006) Gazi Üniversitesi, Bilkent Üniversitesi ve Başkent Üniversitesi'nde turizm eğitimi alan öğrencilere yaptığı çalışmada, öğrencilerin okulun fiziksel görünümü ve imkânlarıyla ilgili beklentilerinin çok yüksek olduğu belirlenmiştir. Özgül ve Devebakan'ın (2005) yaptikları araşttrmada Dokuz Eylül ve Ege Üniversiteleri iiBF İşletme Bölümü öğrencilerinin kendilerine sunulan hizmet kalitesi beklenti ve algılarında farklılık olduğu tespit edilmiştir.

\section{Yöntem}

\section{Araştırmanın Problemi}

Turizmin Türkiye'de 1980 'lerden sonra hızla büyümesiyle ortaya çıkan sorunlardan birisi sektöre eğitimli ve kalifiye işgücü akışııın sağlanamamasıdır (Ergün, 2013: 22). Yapılan araştırmalara göre, turizm eğitimi alanların birçoğu gelecek kaygısı taşımakta, çok az bir bölümü turizm alanında kariyer hedeflemekte ve mezun olduktan sonra turizm sektöründe çalışmaya başlayanlar kısa bir süre sonra sektörü bırakmaktadır (Duman vd., 2014; Baltacı vd., 2012; Pehlivan, 2008; Pelit ve Güçer, 2006). Verilen kalitesiz turizm eğitimiyle ve kalifiye olmayan personel tarafindan sunulan hizmetle Türkiye turizminin modern turizmin gereksinimlerini karşılayabilmesi mümkün görünmemektedir. Bu bağlamda sektöre kalifiye ara eleman yetiştirmeyi amaçlayan TOMYO'ların sunmuş oldukları eğitim-öğretim hizmetinin kalitesinin önemi ortaya çıkmaktadır. Bu okullarda öğrenim gören öğrencilerin okullardan beklentilerinin ne düzeyde karşıllandığının belirlenmesi, TOMYO'ların eğitim-öğretim hizmet kalitelerinin değerlendirilmesi ve geliştirilmesi açısından önem arz etmektedir. Yapılan alan yazın araştırmasında, Türkiye'deki TOMYO'larda öğrenim gören öğrencilerin eğitim-öğretim hizmet kalitesine ilişkin görüşlerinin belirlenmesine yönelik herhangi bir araştırmaya rastlanılmamıştır.

\section{Araştırmanın Amacı ve Önemi}

Bu araştırmanın temel amacı, Türkiye'deki TOMYO'lardaki öğrencilerinin eğitim-öğretim hizmet kalitesine ilişkin görüşlerini ortaya koymak ve bu okulların hizmet kalitesi iyileştirme çabalarına bir katkı sağlamaktır.

Turizmde nitelikli insan gücünün kaynağı olan ön lisans ve lisans düzeyinde eğitim veren okullardır. Yapılan bu araştırma, turizm eğitimini TOMYO'larda ön lisans düzeyinde alan öğrencilerin aldıkları eğitimin hizmet kalitesine ilişkin görüşlerinin belirlenerek, elde edilen veriler ışı̆̆ında turizm meslek yüksekokullarının sundukları eğitim hizmetinin kalitesini gözden geçirmelerine imkân sağlaması açısından önem taşımaktadır.

\section{Araştırmanın Evreni ve Örneklemi}

Yapılan bu araştırmanın evrenini, Türkiye'deki TOMYO'larda öğrenim gören öğrenciler oluşturmaktadır. Türkiye'de 9 adet TOMYO bulunmaktadır. Bu okullar şunlardır:

- Erzincan Üniversitesi Turizm ve Otelcilik Meslek Yüksekokulu

- Gaziantep Üniversitesi Turizm ve Otelcilik Meslek Yüksekokulu

- İnönü Üniversitesi Kale Turizm ve Otel İşletmeciliği Meslek Yüksekokulu

- Karadeniz Teknik Üniversitesi Turizm ve Otelcilik Meslek Yüksekokulu

- Kocaeli Üniversitesi Kartepe Turizm Meslek Yüksekokulu 
- Muğla Sıtkı Koçman Üniversitesi Marmaris Turizm Meslek Yüksekokulu

- Ondokuz Mayıs Üniversitesi Bafra Turizm Meslek Yüksekokulu

- Sakarya Üniversitesi Kırkpınar Turizm Meslek Yüksekokulu

- Süleyman Demirel Üniversitesi Şarkikaraağaç Turizm Meslek Yüksekokulu

Verilerin toplandığı 2015-2016 Akademik yılı itibariyle On Dokuz Mayıs Üniversitesi Bafra Turizm Meslek Yüksekokulu ve Süleyman Demirel Üniversitesi Şarkikaraağaç Turizm Meslek Yüksekokulu'nun henüz öğrenci alımı yapmamış olmalarından dolayı bu iki okulda anket uygulaması yapılamamıştr. Diğer 7 okulun yüksekokul sekreterlikleri ve öğrenci işleriyle tek tek görüşülerek toplam evrenin 3987 olduğu tespit edilmiştir. Evrenin tamamına ulaşmanın hem zaman hem de maliyet açısından güç olacağı göz önüne alındığından örneklem alma yolu tercih edilmiştir. Buna göre, örneklem sayısının belirlenmesinde Bartlett ve diğerlerinin (2001: 48) formülünden yararlanılmış ve örneklem sayısı 350 olarak hesaplanmıştır.

Bu araştırmada 1200 anket formu öğrencilere yaptrılmak üzere okullara gönderilmiş ve bunlardan 930'u geri dönmüştür. Geri dönen anket formlarından 80 tanesi yanlış veya eksik doldurulduğu için değerlendirme dışı bırakılmış ve analizler toplam 850 anket üzerinden gerçekleştirilmiştir. Buna göre, örneklem sayısı evreni temsil etme gücüne sahiptir.

\section{Anket Formunun İçeriği ve Veri Çözümleme Yöntemi}

Bu çalışmada veri toplama aracı olarak anket yöntemi kullanılmıştr. Kullanılacak anket formunu oluşturmak için hizmet kalitesi üzerine yapılan çalışmalar (Parasuraman vd., 1988; Grönross, 1990; Cronin ve Taylor, 1994; Tsang ve Qu, 2000; Akbaba, 2006; Yılmaz, 2007) incelenmiş ve Şahin'in (2009) geliştirdiği “Eğitim Fakültesi-Öğrenci Memnuniyet Ölçeği" temel alınarak anket formu oluşturulmuştur.

Uygulanan anket formu iki bölümden oluşmaktadır. Birinci bölümde, katılımcıların demografik ve tanıtıcı bilgilerinin sorulduğu 15 soru yer almaktadır. Anket formunun ikinci bölümünde ise, TOMYO'larda öğrenim gören öğrencilerin eğitim-öğretim hizmet kalitesine ilişkin görüşlerinin belirlenmesine yönelik 7'li likert ölçeğinde hazırlanmış 33 soru yer almaktadır. Anket sorularının daha iyi anlaşııması ve daha sağlıklı sonuçların elde edilebilmesi için belirlenen katılım ifadeleri 7'den 1'e doğru, "Kesinlikle Kathlıyorum" seçeneğinden başlayarak puanlanmıştır. Verilerin aritmetik ortalamalarının değişim aralığı (range) hesaplanmasında ise aşağıdaki yol izlenmiştir:

Değişim Aralığı (Range) $=7-1=6$

Değişim Aralığı (Range) $=6 / 7=0,85$

\section{Uygulama ve Ölçümün Güvenilirliği}

Ölçeğin güvenilirlik analizi, Cronbach's Alpha katsayı hesaplanarak yapıımıştır. Ölçeğin güvenilirlik katsayısı 0,937'dir. Akbulut’a (2010) göre bu değer, ölçeği oluşturan ifadelerin iç tutarlılık güvenilirliğinin yüksek olduğunu göstermektedir. Bu aşamadan sonra değişkenler arasında yeterli oranda ilişkinin olup olmadığını anlamak için yapılan Bartlett's Küresellik Testi sonucuna göre anketin ikinci bölümündeki 33 ifade için $p=0,000(p<0,05)$ olduğu ve anlamlı olduğu görülmüş ve bu değişkenlerle arasında faktör analizi yapmaya yeterli düzeyde bir ilişki olduğu belirlenmiştir. Daha sonra da Kaiser-Meyer-Olkin (KMO) örneklem yeterlilik değerinin 0,936 olduğu ve örneklemin büyüklüğünün faktör analizi için yeterli olduğu tespit edilmiştir.

Ölçek faktörlerinin belirlenmesi aşamasında faktör yükü iki faktöre yüklenen maddelerin her iki faktördeki faktör yük değerlerinin arasındaki farkların 0,10'dan yüksek olmasından dolayı ölçekte çapraz yüklenme olmadığı görülmüş (Gürbüz ve Şahin, 2015: 312) ve ölçekte herhangi bir binişik maddenin olmadığı tespit edilmiştir. Sonuç olarak yapılan güvenilirlik analizinden sonra 33 ifadeli ölçeğin 6 faktörden oluştuğu, faktörlerin toplam varyansın \%60,063'ünü açıkladığı ve maddelerin faktör yüklerinin 0,4'ün üzerinde olduğu görülmüştür. Bu faktörler; öğretim elemanlarından alınan hizmet (1.faktör), yönetimsel hizmet (2.faktör), danışmandan alınan destek hizmeti (3.faktör), bilişim-teknoloji olanakları hizmeti (4.faktör), dersler ve ders programları hizmeti (5.faktör) ve fiziksel olanaklar hizmeti (6.faktör) olarak isimlendirilmiştir.

\section{Bulgular}

Bu çalışmadaki bulgular; araştırmaya ilişkin demografik ve tanıtıı bilgiler, TOMYO'larda öğrenim gören öğrencilerin eğitim-öğretim hizmet kalitesine ilişkin görüşlerine ilişkin bulgular ve diğer bulgular olmak üzere üç bölümde incelenmiştir. 


\section{Demografik ve Tanıtıcı Bilgilere İlişkin Bulgular}

Araştırmaya katılan öğrencilerin demografik ve tanıtıcı özelliklerini belirlemeye yönelik; cinsiyet, yaş, okul, bölüm, sınıf ve not ortalaması olmak üzere alt soru sorulmuş ve elde edilen bulgulara ait frekans ve yüzde değerleri Tablo 1'de sunulmuştur.

Tablo 1. Araştırmaya Katılan Öğrencilerin Demografik ve Tanıtıcı Bilgilerinin Frekans ve Yüzde Dağılımları

\begin{tabular}{|c|c|c|}
\hline Cinsiyet & $f$ & $\%$ \\
\hline Erkek & 436 & 51,3 \\
\hline Kız & 414 & 48,7 \\
\hline Yaş & $f$ & $\%$ \\
\hline $20-22$ & 565 & 66,5 \\
\hline 19 ve alt & 177 & 20,8 \\
\hline $23-25$ & 86 & 10,1 \\
\hline 26 ve üzeri & 22 & 2,6 \\
\hline Okul & $\mathrm{f}$ & $\%$ \\
\hline Gaziantep TOMYO & 172 & 20,2 \\
\hline Muğla Sıtkı Koçman Üniversitesi Marmaris TMYO & 136 & 16,0 \\
\hline Sakarya Üniversitesi Kırkpınar TMYO & 135 & 15,9 \\
\hline Kocaeli Üniversitesi Kartepe TMYO & 132 & 15,5 \\
\hline KATÜ TOMYO & 120 & 14,1 \\
\hline Erzincan Üniversitesi TOMYO & 92 & 10,8 \\
\hline İnönü Üniversitesi Kale TOIMYO & 63 & 7,5 \\
\hline Bölüm & $f$ & $\%$ \\
\hline Seyahat, Turizm ve Eğlence Hizmetleri & 424 & 49,9 \\
\hline Otel, Lokanta ve İkram Hizmetleri & 406 & 47,7 \\
\hline Pazarlama ve Reklamcılık & 20 & 2,4 \\
\hline Sinıf & $f$ & $\%$ \\
\hline 1 & 436 & 51,3 \\
\hline 2 & 414 & 48,7 \\
\hline Not Ortalaması & $f$ & $\%$ \\
\hline $2,00-2,99$ & 489 & 57,5 \\
\hline $1,00-1,99$ & 189 & 22,2 \\
\hline $3,00-4,00$ & 152 & 17,9 \\
\hline $0-0,99$ & 20 & 2,4 \\
\hline TOPLAM & 850 & 100,0 \\
\hline
\end{tabular}

Tablo 1'de görüldüğü üzere; araştırmaya katılanların \%48,7'si kız, \%51,3'ü erkektir. Yaş aralıklarına bakıldığında katlımcıların çoğunun \%66,5 ile 20-22 yaş aralığında, en az da \%2,6 ile 26 ve üzeri yaşta oldukları görülmektedir. Öğrencilerin $\% 51,3$ 'ü 1. sınıfta, \%48,7'si 2. sınıfta, \%49,9'la en çok seyahat, turizm ve eğlence hizmetleri bölümünde öğrenim görmektedirler. Araştırmaya katılan öğrencilerin not ortalamalarına bakıldığında \%57,5 ile 2,00-2,99 aralığında en çok, en az da \%2,4 ile 0-0,99 aralığında not ortalamalarına sahip oldukları görülmektedir.

Turizm ve Otelcilik Meslek Yüksekokulları'nda Öğrenim Gören Öğrencilerin Eğitim-Öğretim Hizmet Kalitesine İlişkin Görüşlerine Ait Bulgular

Merkezi limit teoremine göre, bir araştırmanın örneklem sayısı büyük olduğu zaman örneklemin genellendiği evren normal dağılıma sahip olmasa ya da yapılan analizler yeterince güvenilir biçimde olmasa bile örneklemin merkezi eğilimi normal bir dağılım gösterebilmektedir. Bazı kaynaklarda $n>30$ ya da $n>100$ olduğu şartlarda parametrik test koşullarının oluştuğu söylenmektedir (Akbulut, 2010: 19). Merkezi limit teoremine göre örneklem sayısı fazla olduğu için $(\mathrm{n}=850)$ normallik varsayımı kabul edilmiştir ve parametrik testlerin kullanılmasına karar verilmiştir.

Araştirmaya katılan TOMYO'larda öğrenim gören öğrencilerin eğitim-öğretim hizmet kalitesine ilişkin görüşlerinden elde edilen bulgulara göre, kendilerine sorulan 33 sorudan 29'una olumlu, 4 tanesine de kararsız görüş bildirdikleri ve hiçbir soruya olumsuz görüş bildirmedikleri görülmüştür. Buna göre, öğrencilerin eğitim-öğretim hizmet kalitesine ilişkin görüşlerinin ağılıklı ortalaması olumludur. 
Bununla beraber öğrencilerin eğitim-öğretim hizmet kalitesine ilişkin görüşleri ile öğrenim gördükleri okullar arasında anlamlı bir farklılık olup olmadığı tek yönlü Anova Testi ile ölçülmüş ve sonuçlar Tablo 2'de gösterilmiştir.

Tablo 2. Öğrencilerin Eğitim-Öğretim Hizmet Kalitesine İlişkin Görüşleri Ille Öğrenim Gördükleri Okulların Tek Yönlü Anova Testi Sonuçları

\begin{tabular}{|c|c|c|c|c|c|c|c|}
\hline \multirow{2}{*}{ Okul } & \multirow{2}{*}{$\mathrm{N}$} & \multirow{2}{*}{ Ortalama } & \multirow{2}{*}{ Standart Sapma } & \multicolumn{2}{|c|}{ \%95 Güven Aralığı } & \multirow{2}{*}{$f$} & \multirow{2}{*}{$p$} \\
\hline & & & & Alt Sınır & Üst Sınır & & \\
\hline Sakarya & 135 & 5,4025 & 90223 & 5,2489 & 5,5561 & \multirow{8}{*}{17,650} & \multirow{8}{*}{, $000 *$} \\
\hline İnönü & 63 & 5,3665 & 88920 & 5,1426 & 5,5905 & & \\
\hline Erzincan & 92 & 5,2276 & 1,04252 & 5,0117 & 5,4435 & & \\
\hline Muğla & 136 & 5,1992 & ,97498 & 5,0339 & 5,3645 & & \\
\hline Kocaeli & 132 & 4,7626 & 1,00338 & 4,5899 & 4,9354 & & \\
\hline Gaziantep & 172 & 4,5958 & ,98158 & 4,4481 & 4,7436 & & \\
\hline KATÜ & 120 & 4,5455 & 97088 & 4,3700 & 4,7209 & & \\
\hline TOPLAM & 850 & 4,9648 & 1,02611 & 4,8957 & 5,0339 & & \\
\hline
\end{tabular}

Yapılan tek yönlü Anova analizi sonuçlarına göre öğrencilerin hizmet kalitesine ilişkin görüşleri ile öğrenim gördükleri okullar arasında anlamlı düzeyde bir farklılık olduğu görülmüştür $(p<0,05)$. Bu farklılığın hangi okullar arasında olduğunun tespit edilmesi amacıyla Tukey Testi yapılmış ve sonuçlar Tablo 3'te verilmiştir.

Tablo 3. Öğrencilerin Öğrenim Gördükleri Okullara Göre Eğitim-Öğretim Hizmet Kalitesine iliş̧kin Görüşleri Tukey Testi Sonuçları

\begin{tabular}{|c|c|c|c|c|c|c|}
\hline \multirow{2}{*}{ Okul } & \multirow{2}{*}{ Okul } & \multirow{2}{*}{ Ortalama } & \multirow{2}{*}{ Standart Sapma } & \multirow{2}{*}{$p$} & \multicolumn{2}{|c|}{ \%95 Güven Aralığı } \\
\hline & & & & & Alt Sınır & Üst Sınır \\
\hline \multirow{6}{*}{ Gaziantep } & İnönü &,$- 77068 *$ & 14293 & ,000 & $-1,1931$ &,- 3482 \\
\hline & Erzincan &,$- 63176 *$ & 12537 & ,000 & $-1,0023$ &,- 2612 \\
\hline & Kocaeli &,- 16678 & 11231 & ,754 &,- 4987 & 1651 \\
\hline & KATÜ & ,05039 & 11544 & 999 &,- 2908 & ,3916 \\
\hline & Sakarya &,$- 80663 *$ & 11160 & ,000 & $-1,1365$ &,- 4768 \\
\hline & Muğla &,$- 60336 *$ & 11137 & ,000 &,- 9325 &,- 2742 \\
\hline \multirow{6}{*}{ İnönü } & Gaziantep & ,77068* & 14293 & ,000 & ,3482 & 1,1931 \\
\hline & Erzincan & 13892 & 15872 & 976 &,- 3302 & ,6080 \\
\hline & Kocaeli & ,60390* & 14863 & ,001 & 1646 & 1,0432 \\
\hline & KATÜ & ,82107* & 15101 & ,000 & 3748 & 1,2674 \\
\hline & Sakarya &,- 03595 & 14809, & 1,000 &,- 4736 & 4017 \\
\hline & Muğla & ,16732 & 14792 & ,918 &,- 2698 & 6045 \\
\hline \multirow{6}{*}{ Erzincan } & Gaziantep &, $63176 *$ & ,12537 &, 000 & 2612 & 1,0023 \\
\hline & İnönü &,- 13892 & 15872 & 976 &,- 6080 & ,3302 \\
\hline & Kocaeli & ,46498* & 13182 & ,008 & ,0754 & ,8546 \\
\hline & KATÜ &, $68215^{*}$ & 13450, & ,000 & 2846 & 1,0797 \\
\hline & Sakarya &,- 17487 & 13122, & ,836 &,- 5627 & ,2129 \\
\hline & Muğla & ,02840 & 13102 & 1,000 &,- 3588 & ,4156 \\
\hline \multirow{6}{*}{ Kocaeli } & Gaziantep & 16678 & 11231 & ,754 &,- 1651 & 4987 \\
\hline & İnönü &,$- 60390 *$ & 14863, & ,001 & $-1,0432$ &,- 1646 \\
\hline & Erzincan &,$- 46498 *$ & 13182 & ,008 &,- 8546 &,- 0754 \\
\hline & KATÜ & ,21717 & 12242, & ,566 &,- 1446 & ,5790 \\
\hline & Sakarya &,$- 63984 *$ & 11881, & ,000 & -,9910 &,- 2887 \\
\hline & Muğla &,$- 43657^{*}$ & 11859 &, 005 &,- 7871 &,- 0861 \\
\hline \multirow{6}{*}{ KATÜ } & Gaziantep &,- 05039 & 11544, & 999 &,- 3916 & 2908 \\
\hline & İnönü &,$- 82107^{*}$ & 15101, & ,000 & $-1,2674$ &,- 3748 \\
\hline & Erzincan &,$- 68215^{*}$ & 13450, & ,000 & $-1,0797$ &,- 2846 \\
\hline & Kocaeli &,- 21717 & 12242 & ,566 &,- 5790 & 1446 \\
\hline & Sakarya &,$- 85701^{*}$ & 12177, & ,000 & $-1,2169$ &,- 4971 \\
\hline & Muğla &,$- 65374 *$ & ,12156 & ,000 & $-1,0130$ &,- 2945 \\
\hline
\end{tabular}




\begin{tabular}{|c|c|c|c|c|c|c|}
\hline \multirow{2}{*}{ Okul } & \multirow{2}{*}{ Okul } & \multirow{2}{*}{ Ortalama } & \multirow{2}{*}{ Standart Sapma } & \multirow{2}{*}{$\mathrm{p}$} & \multicolumn{2}{|c|}{ \%95 Güven Aralığı } \\
\hline & & & & & Alt Sınır & Üst Sınır \\
\hline \multirow{6}{*}{ Sakarya } & Gaziantep & ,80663* & 11160 & ,000 & ,4768 & 1,1365 \\
\hline & İnönü & ,03595 & 14809 & 1,000 &,- 4017 & ,4736 \\
\hline & Erzincan & 17487 & 13122 & ,836 &,- 2129 & ,5627 \\
\hline & Kocaeli & ,63984* & 11881 & ,000 & 2887 & 9910 \\
\hline & KATÜ & ,85701* & 12177 & ,000 & 4971 & 1,2169 \\
\hline & Muğla & ,20327 & 11792 & ,600 &,- 1452 &, 5518 \\
\hline \multirow{6}{*}{ Muğla } & Gaziantep & ,60336* & 11137 & ,000 & ,2742 & 9325 \\
\hline & İnönü &,- 16732 & 14792 & 918 &,- 6045 & 2698 \\
\hline & Erzincan &,- 02840 & 13102 & 1,000 &,- 4156 & 3588 \\
\hline & Kocaeli & ,43657* & 11859 &, 005 & ,0861 & 7871 \\
\hline & KATÜ &, $65374^{*}$ & 12156 & ,000 & 2945 & 1,0130 \\
\hline & Sakarya &,- 20327 & 11792 & ,600 &,- 5518 & ,1452 \\
\hline
\end{tabular}

Analiz sonucuna göre, evren içinde yer alan üniversitelerde öğrenim gören öğrencilerin eğitim-öğretim hizmet kalitesine ilişkin görüşlerinin puan ortalamaları arasında anlamlı bir farklılık olduğu görülmüştür. Bu okullardan Sakarya Üniversitesi Kırkpınar TMYO öğrencilerinin genel hizmet kalitesi algısının ortalama değeri diğer bütün okullardan pozitif yönde, Karadeniz Teknik Üniversitesi TOMYO öğrencilerinin genel hizmet kalitesi algısının ortalaması ise diğer bütün okullardan negatif yönde farklılık göstermektedir.

Üniversitelere göre, ölçekte belirlenen alt faktöre ilişkin hizmet kalitesinin farklılaşıp farklılaşmadığının tespit edilebilmesi için tek yönlü Anova testi uygulanmıştır. Her bir faktöre ilişkin veriler aşağıda tablolar halinde sunulmuştur.

Tablo 4: Üniversite Değişkeni Açısından Öğretim Elemanlarından Alınan Hizmet Kalitesi Faktörüne İlişkin Tek Yönlü Anova Testi Sonuçları

\begin{tabular}{|c|c|c|c|c|c|c|c|c|}
\hline & \multirow{2}{*}{ Okul } & \multirow{2}{*}{$\mathrm{N}$} & \multirow{2}{*}{ Ortalama } & \multirow{2}{*}{$\begin{array}{c}\text { Standart } \\
\text { Sapma }\end{array}$} & \multicolumn{2}{|c|}{ \%95 Güven Aralığı } & \multirow{2}{*}{$f$} & \multirow{2}{*}{$\mathrm{p}$} \\
\hline & & & & & Alt Sınır & Üst Sınır & & \\
\hline \multirow{8}{*}{ 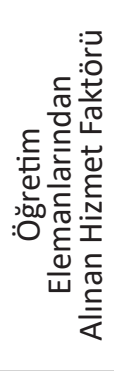 } & İnönü & 63 & 5,5571 & 92714 & 5,3236 & 5,7906 & \multirow{8}{*}{3,213} & \multirow{8}{*}{,004* } \\
\hline & Sakarya & 135 & 5,4674 & 1,06602 & 5,2859 & 5,6489 & & \\
\hline & Muğla & 136 & 5,4360 & 1,07288 & 5,2541 & 5,6180 & & \\
\hline & Erzincan & 92 & 5,2641 & 1,29874 & 4,9952 & 5,5331 & & \\
\hline & KATÜ & 120 & 5,2483 & ,93862 & 5,0787 & 5,4180 & & \\
\hline & Kocaeli & 132 & 5,1318 & 1,03336 & 4,9539 & 5,3097 & & \\
\hline & Gaziantep & 172 & 5,0919 & 1,08549 & 4,9285 & 5,2552 & & \\
\hline & TOPLAM & 850 & 5,2880 & 1,07583 & 5,2156 & 5,3604 & & \\
\hline
\end{tabular}

$* p \leq 0,05$

Buna göre üniversite değişkeni açısından öğretim elemanlarından alınan hizmet kalitesi algısında anlamlı bir farkIılaşma tespit edilmiştir $(p<0,05)$.

Tablo 5. Üniversite Değişkeni Açısından Yönetimsel Hizmet Kalitesi Faktörüne ilişkin Tek Yönlü Anova Testi Sonuçları

\begin{tabular}{|c|c|c|c|c|c|c|c|c|}
\hline & \multirow{2}{*}{ Okul } & \multirow{2}{*}{$\mathrm{N}$} & \multirow{2}{*}{ Ortalama } & \multirow{2}{*}{$\begin{array}{c}\text { Standart } \\
\text { Sapma }\end{array}$} & \multicolumn{2}{|c|}{ \%95 Güven Aralığı } & \multirow{2}{*}{$f$} & \multirow{2}{*}{$p$} \\
\hline & & & & & Alt Sınır & Üst Sınır & & \\
\hline \multirow{8}{*}{ 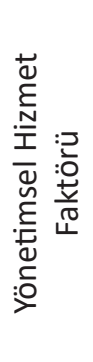 } & Sakarya & 135 & 5,1577 & 1,11292 & 4,9682 & 5,3471 & \multirow{8}{*}{12,487} & \multirow{8}{*}{,000* } \\
\hline & Muğla & 136 & 4,9296 & 1,17469 & 4,7304 & 5,1288 & & \\
\hline & İnönü & 63 & 4,8549 & 1,23571 & 4,5437 & 5,1661 & & \\
\hline & Erzincan & 92 & 4,5248 & 1,33679 & 4,2480 & 4,8017 & & \\
\hline & Kocaeli & 132 & 4,3387 & 1,38318 & 4,1006 & 4,5769 & & \\
\hline & Gaziantep & 172 & 4,2467 & 1,39073 & 4,0374 & 4,4560 & & \\
\hline & KATÜ & 120 & 4,0524 & 1,40288 & 3,7988 & 4,3060 & & \\
\hline & TOPLAM & 850 & 4,5627 & 1,35195 & 4,4717 & 4,6537 & & \\
\hline
\end{tabular}

Analiz sonucuna göre yönetimsel hizmet kalitesi algı düzeyinde üniversite değişkeni açısından anlamlı bir farklılaşma 
olduğu görülmektedir. Yönetimsel hizmet faktörü bakımından hizmet kalitesi algııının en yüksek olduğu okulun Sakarya Üniversitesi Kırkpınar TMYO olduğu belirlenmiştir.

Tablo 6. Üniversite Değişkeni Açısından Danışmandan Alınan Hizmet Kalitesi Faktörüne İlişkin Tek Yönlü Anova Testi Sonuçları

\begin{tabular}{|c|c|c|c|c|c|c|c|c|}
\hline & \multirow{2}{*}{ Okul } & \multirow{2}{*}{$\mathrm{N}$} & \multirow{2}{*}{ Ortalama } & \multirow{2}{*}{$\begin{array}{c}\text { Standart } \\
\text { Sapma }\end{array}$} & \multicolumn{2}{|c|}{ \%95 Güven Aralığı } & \multirow{2}{*}{$f$} & \multirow{2}{*}{$\mathrm{p}$} \\
\hline & & & & & Alt Sınır & Üst Sınır & & \\
\hline \multirow{8}{*}{ 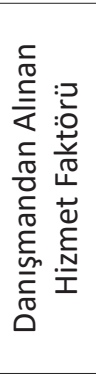 } & İnönü & 63 & 5,5635 & 1,36560 & 5,2196 & 5,9074 & \multirow{8}{*}{6,046} & \multirow{8}{*}{, $000 *$} \\
\hline & Sakarya & 135 & 5,3519 & 1,31165 & 5,1286 & 5,5751 & & \\
\hline & Erzincan & 92 & 5,3424 & 1,41941 & 5,0484 & 5,6363 & & \\
\hline & Muğla & 136 & 5,3162 & 1,36803 & 5,0842 & 5,0253 & & \\
\hline & Gaziantep & 172 & 5,1497 & 1,44025 & 4,9329 & 5,5482 & & \\
\hline & Kocaeli & 132 & 4,7500 & 1,59914 & 4,4747 & 5,3665 & & \\
\hline & KATÜ & 120 & 4,6333 & 1,57613 & 4,3484 & 4,9182 & & \\
\hline & TOPLAM & 850 & 5,1250 & 1,47357 & 5,0258 & 5,2242 & & \\
\hline
\end{tabular}

Buna göre üniversite değişkeni açısından danışmandan alınan destek hizmeti kalitesinde öğrenci görüşlerine göre anlamlı bir farklılaşma tespit edilmiştir $(P<0,05)$.

Tablo 7. Üniversite Değişkeni Açısından Bilişim-Teknoloji Olanakları Hizmet Kalitesi Faktörüne ílişkin Tek Yönlü Anova Testi Sonuçları

\begin{tabular}{|c|c|c|c|c|c|c|c|c|}
\hline & \multirow{2}{*}{ Okul } & \multirow{2}{*}{$\mathrm{N}$} & \multirow{2}{*}{ Ortalama } & \multirow{2}{*}{$\begin{array}{c}\text { Standart } \\
\text { Sapma }\end{array}$} & \multicolumn{2}{|c|}{ \%95 Güven Aralığı } & \multirow{2}{*}{$f$} & \multirow{2}{*}{$\mathrm{p}$} \\
\hline & & & & & Alt Sınır & Üst Sınır & & \\
\hline \multirow{8}{*}{ 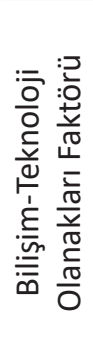 } & Erzincan & 92 & 5,8043 & 1,32745 & 5,5294 & 6,0793 & \multirow{8}{*}{72,006} & \multirow{8}{*}{, $000 *$} \\
\hline & İnönü & 63 & 5,6468 & 1,26653 & 5,3279 & 5,9658 & & \\
\hline & Sakarya & 135 & 5,5722 & 1,15249 & 5,3760 & 5,7684 & & \\
\hline & Muğla & 136 & 4,9504 & 1,33847 & 4,7234 & 5,1774 & & \\
\hline & Kocaeli & 132 & 4,0133 & 1,66329 & 3,7269 & 4,2996 & & \\
\hline & KATÜ & 120 & 3,5354 & 1,52751 & 3,2593 & 3,8115 & & \\
\hline & Gaziantep & 172 & 2,9826 & 1,79334 & 2,7126 & 3,2525 & & \\
\hline & TOPLAM & 850 & 4,4497 & 1,82531 & 4,3268 & 4,5726 & & \\
\hline
\end{tabular}

Üniversite değişkeni açısından bilişim-teknoloji olanakları hizmet kalitesinde anlamlı bir farklılaşma vardır $(p<0,05)$.

Tablo 8. Üniversite Değişkeni Açısından Dersler ve Derslerin Programlanmasıyla İlgili Hizmet Kalitesi Faktörüne İlişkin Tek Yönlü Anova Testi Sonuçları

\begin{tabular}{|c|c|c|c|c|c|c|c|c|}
\hline & \multirow{2}{*}{ Okul } & \multirow{2}{*}{$\mathrm{N}$} & \multirow{2}{*}{ Ortalama } & \multirow{2}{*}{$\begin{array}{c}\text { Standart } \\
\text { Sapma }\end{array}$} & \multicolumn{2}{|c|}{ \%95 Güven Aralığı } & \multirow{2}{*}{$f$} & \multirow{2}{*}{$p$} \\
\hline & & & & & Alt Sınır & Üst Sınır & & \\
\hline \multirow{8}{*}{ 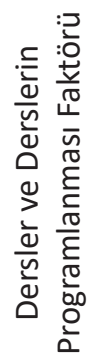 } & İnönü & 63 & 5,4841 & 1,48980 & 5,1089 & 5,8593 & \multirow{8}{*}{4,841} & \multirow{8}{*}{,000* } \\
\hline & Muğla & 136 & 5,1728 & 1,34251 & 4,9451 & 5,4005 & & \\
\hline & Erzincan & 92 & 5,1712 & 1,54107 & 4,8520 & 5,4903 & & \\
\hline & Sakarya & 135 & 5,4241 & 1,20101 & 5,2196 & 5,6285 & & \\
\hline & KATÜ & 120 & 5,0563 & 1,29538 & 4,8221 & 5,2904 & & \\
\hline & Kocaeli & 132 & 4,8542 & 1,59975 & 4,5787 & 5,1296 & & \\
\hline & Gaziantep & 172 & 4,7006 & 1,54552 & 4,4680 & 4,9332 & & \\
\hline & TOPLAM & 850 & 5,0741 & 1,45342 & 4,9763 & 5,1720 & & \\
\hline
\end{tabular}

Öğrenci görüşlerine göre, okullarda verilen dersler ve bu derslerin programlanmasına ilişkin hizmet kalitesinde üniversite değişkeni açısından anlamlı bir farklılaşma olduğu tespit edilmiştir $(p<0,05)$. 
Tablo 9. Üniversite Değişkeni Açısından Fiziksel Olanaklar Hizmet Kalitesi Faktörüne ilişkin Tek Yönlü Anova Testi Sonuçları

\begin{tabular}{|c|c|c|c|c|c|c|c|c|}
\hline & \multirow{2}{*}{ Okul } & \multirow{2}{*}{$\mathrm{N}$} & \multirow{2}{*}{ Ortalama } & \multirow{2}{*}{$\begin{array}{c}\text { Standart } \\
\text { Sapma }\end{array}$} & \multicolumn{2}{|c|}{ \%95 Güven Aralığı } & \multirow{2}{*}{$f$} & \multirow{2}{*}{$p$} \\
\hline & & & & & Alt Sınır & Üst Sınır & & \\
\hline \multirow{8}{*}{ 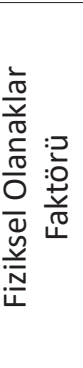 } & Erzincan & 92 & 5,7310 & 1,17450 & 5,4877 & 5,9742 & \multirow{8}{*}{21,768} & \multirow{8}{*}{, $000 *$} \\
\hline & Sakarya & 135 & 5,5278 & 1,02836 & 5,3527 & 5,7028 & & \\
\hline & Kocaeli & 132 & 5,2519 & 1,13560 & 5,0564 & 5,4474 & & \\
\hline & Muğla & 136 & 5,2371 & 1,30004 & 5,0167 & 5,4576 & & \\
\hline & İnönü & 63 & 5,1905 & 1,29649 & 4,8640 & 5,5170 & & \\
\hline & Gaziantep & 172 & 4,9215 & 1,33348 & 4,7208 & 5,1222 & & \\
\hline & KATÜ & 120 & 4,0625 & 1,39524 & 3,8103 & 4,3147 & & \\
\hline & TOPLAM & 850 & 5,1059 & 1,33201 & 5,0162 & 5,1956 & & \\
\hline
\end{tabular}

Fiziksel olanaklar hizmet kalitesi algı düzeyinde, üniversite değişkeni açısından istatistiksel olarak anlamlı bir farklılaşma tespit edilmiştir $(\mathrm{p}<0,05)$.

\section{Diğer Bulgular}

Bu bölümde, araştırmaya katılan öğrencilerin eğitim-öğretim hizmet kalitesine ilişkin görüşlerinin bazı demografik verilere ve anket formunun birinci bölümünde sorulan sorulara verdikleri yanıtlara göre farklılaşıp farklılaşmadığına, öğrencilerin öğrenim gördükleri okullara göre mezuniyet sonrası kolay iş bulabilme düşüncelerine ve mezuniyet sonrası eğitime devam etme isteklerine ve son olarak da öğrencilerin öğrenim gördükleri programı isteyerek tercih etmeleri ile programı şu an sevme durumları arasındaki ilişkiye yönelik yapılan analizler yer almaktadır.

Tablo 10. Öğrencilerin Eğitim-Öğretim Hizmet Kalitesine İlişkin Görüşleri ve Not Ortalamalarına Yönelik Tek Yönlü Anova Testi Sonuçları

\begin{tabular}{|c|c|c|c|c|c|c|c|}
\hline \multirow{2}{*}{ Not Ortalaması } & \multirow{2}{*}{$\mathrm{N}$} & \multirow{2}{*}{ Ortalama } & \multirow{2}{*}{$\begin{array}{l}\text { Standart } \\
\text { Sapma }\end{array}$} & \multicolumn{2}{|c|}{ \%95 Güven Aralığı } & \multirow{2}{*}{$f$} & \multirow{2}{*}{$\mathrm{p}$} \\
\hline & & & & Alt Sınır & Üst Sınır & & \\
\hline $1.00-1.99$ & 189 & 5,0515 & 1,03740 & 4,9026 & 5,2003 & & \\
\hline $3.00-4.00$ & 152 & 4,9940 & 1,04351 & 4,8268 & 5,1613 & & \\
\hline $2.00-2.99$ & 489 & 4,9391 & 1,01889 & 4,8486 & 5,0296 & 1,678 & 170 \\
\hline $0-0.99$ & 20 & 4,5515 & ,89627 & 4,1320 & 4,9710 & & \\
\hline TOPLAM & 850 & 4,9648 & 1,02611 & 4,8957 & 5,0339 & & \\
\hline
\end{tabular}

Buna göre öğrencilerin eğitim-öğretim hizmet kalitesine ilişkin görüşlerinde öğrencilerin akademik başarı ortalamalarına göre anlamlı bir farklılaşma tespit edilememiştir $(p>0,05)$.

Tablo 11. Cinsiyet Değişkeni Açısından Hizmet Kalitesi Algısındaki Farklılaşma T Testi Sonuçları

\begin{tabular}{|c|c|c|c|c|c|c|}
\hline Cinsiyet & $\mathrm{N}$ & Ortalama & Standart Sapma & s.d. & $\mathrm{t}$ & $p$ \\
\hline $\mathrm{KIz}$ & 414 & 5,0354 & ,98945 & \multirow{2}{*}{848} & \multirow{2}{*}{1,959} & \multirow{2}{*}{,050* } \\
\hline Erkek & 436 & 4,8977 & 1,05651 & & & \\
\hline
\end{tabular}

Yapılan t testi sonucunda öğrencilerin cinsiyetlerine göre eğitim-öğretim hizmet kalitesine ilişkin görüşleri arasında anlamlı bir farklılık görülmüştür. Buna göre kız öğrencilerin eğitim-öğretim hizmet kalitesi algısına ilişkin görüşlerinin ortalaması, erkek öğrencilerin ortalamasından daha yüksektir.

Tablo 12. Öğrencilerin Eğitim Aldıkları Programı Şu An Sevme Durumları Açısından Hizmet Kalitesi Algısındaki FarkIılaşma T Testi Sonuçları

\begin{tabular}{lcccccc}
\hline Programı Şu Anda Sevme Durumu & N & Ortalama & Standart Sapma & s.d. & t & p \\
\hline Evet & 576 & 5,1619 &, 96283 & 848 & 8,452 & ,000* \\
Hayır & 274 & 4,5503 & 1,03317 & & &
\end{tabular}


Şu an eğitim aldığı bölümü seven öğrencilerin hizmet kalitesi algı düzeylerinin sevmeyenlere göre yüksek olduğu görülmüştür. Öğrencilerin eğitim-öğretim hizmet kalitesine ilişkin görüşleri ile öğrenim gördüğü bölümünü şu anda sevme durumları arasındaki farklılaşma istatistiksel olarak anlamlıdır $(p<0,05)$.

Tablo 13. Öğrencilerin Öğrenim Gördükleri Okullara Göre Mezuniyet Sonrası Eğitime Devam Etme Durumları Ki-Kare Testi

\begin{tabular}{|c|c|c|c|c|c|c|c|c|}
\hline \multirow{2}{*}{ Okul } & & \multicolumn{3}{|c|}{ Eğitime Devam Etme Durumu } & \multirow{2}{*}{ Toplam } & \multirow{2}{*}{ Ki-Kare X² } & \multirow{2}{*}{ s.d. } & \multirow{2}{*}{$\mathrm{p}$} \\
\hline & & Evet & Kararsızım & Hayır & & & & \\
\hline \multirow{2}{*}{ Muğla } & $\mathrm{N}$ & 90 & 32 & 14 & 136 & \multirow{16}{*}{9,995} & \multirow{16}{*}{12} & \multirow{16}{*}{,616 } \\
\hline & $\%$ & $\% 66,2$ & $\% 23,5$ & $\% 10,3$ & $\% 100,0$ & & & \\
\hline \multirow{2}{*}{ İnönü } & $\mathrm{N}$ & 40 & 17 & 6 & 63 & & & \\
\hline & $\%$ & $\% 63,5$ & $\% 27,0$ & $\% 9,5$ & $\% 100,0$ & & & \\
\hline \multirow{2}{*}{ Gaziantep } & $\mathrm{N}$ & 107 & 49 & 16 & 172 & & & \\
\hline & $\%$ & $\% 62,2$ & $\% 28,5$ & $\% 9,3$ & $\% 100,0$ & & & \\
\hline \multirow{2}{*}{ KATÜ } & $\mathrm{N}$ & 73 & 31 & 16 & 120 & & & \\
\hline & $\%$ & $\% 60,8$ & $\% 25,8$ & $\% 13,3$ & $\% 100,0$ & & & \\
\hline \multirow{2}{*}{ Erzincan } & $\mathrm{N}$ & 54 & 27 & 11 & 92 & & & \\
\hline & $\%$ & $\% 58,7$ & $\% 29,3$ & $\% 12,0$ & $\% 100,0$ & & & \\
\hline \multirow{2}{*}{ Sakarya } & $\mathrm{N}$ & 77 & 48 & 10 & 135 & & & \\
\hline & $\%$ & $\% 57,0$ & $\% 35,6$ & $\% 7,4$ & $\% 100,0$ & & & \\
\hline \multirow{2}{*}{ Kocaeli } & $\mathrm{N}$ & 72 & 46 & 14 & 132 & & & \\
\hline & $\%$ & $\% 54,5$ & $\% 34,8$ & $\% 10,6$ & $\% 100,0$ & & & \\
\hline \multirow{2}{*}{ TOPLAM } & $N$ & 513 & 250 & 87 & 850 & & & \\
\hline & $\%$ & $\% 60,4$ & $\% 29,4$ & $\% 10,2$ & $\% 100,0$ & & & \\
\hline
\end{tabular}

Yapılan ki-kare testi sonucunda öğrencilerin mezuniyet sonrası eğitime devam etme durumlarının öğrenim gördükleri okullara göre dağılımında anlamlı düzeyde farklılık tespit edilememiştir $(p>0,05)$.

Tablo 14. Öğrencilerin Öğrenim Gördükleri Okullara Göre Mezuniyet Sonrası Kolay İş Bulabilme Düşünceleri Ki-Kare Testi Sonuçları

\begin{tabular}{|c|c|c|c|c|c|c|c|c|}
\hline \multirow{2}{*}{ Okul } & & \multicolumn{3}{|c|}{ Kolay İş Bulabilme Düşünceleri } & \multirow{2}{*}{ Toplam } & \multirow{2}{*}{ Ki-Kare $X^{2}$} & \multirow{2}{*}{ s.d. } & \multirow{2}{*}{$\mathrm{p}$} \\
\hline & & Evet & Kararsızım & Hayır & & & & \\
\hline \multirow{2}{*}{ Sakarya } & $\mathrm{N}$ & 72 & 46 & 17 & 135 & \multirow{16}{*}{33,889} & \multirow{16}{*}{12} & \multirow{16}{*}{, $001^{*}$} \\
\hline & $\%$ & $53,3 \%$ & $34,1 \%$ & $12,6 \%$ & $100,0 \%$ & & & \\
\hline \multirow{2}{*}{ Muğla } & $\mathrm{N}$ & 67 & 50 & 19 & 136 & & & \\
\hline & $\%$ & $49,3 \%$ & $36,8 \%$ & $14,0 \%$ & $100,0 \%$ & & & \\
\hline \multirow{2}{*}{ KATÜ } & $\mathrm{N}$ & 57 & 44 & 19 & 120 & & & \\
\hline & $\%$ & $47,5 \%$ & $36,7 \%$ & $15,8 \%$ & $100,0 \%$ & & & \\
\hline \multirow{2}{*}{ Kocaeli } & $\mathrm{N}$ & 58 & 43 & 31 & 132 & & & \\
\hline & $\%$ & $43,9 \%$ & $32,6 \%$ & $23,5 \%$ & $100,0 \%$ & & & \\
\hline \multirow{2}{*}{ İnönü } & $\mathrm{N}$ & 26 & 26 & 11 & 63 & & & \\
\hline & $\%$ & $41,3 \%$ & $41,3 \%$ & $17,5 \%$ & $100,0 \%$ & & & \\
\hline \multirow{2}{*}{ Erzincan } & $\mathrm{N}$ & 35 & 36 & 21 & 92 & & & \\
\hline & $\%$ & $38,0 \%$ & $39,1 \%$ & $22,8 \%$ & $100,0 \%$ & & & \\
\hline \multirow{2}{*}{ Gaziantep } & $\mathrm{N}$ & 54 & 62 & 56 & 172 & & & \\
\hline & $\%$ & $31,4 \%$ & $36,0 \%$ & $32,6 \%$ & $100,0 \%$ & & & \\
\hline \multirow{2}{*}{ TOPLAM } & $\mathrm{N}$ & 369 & 307 & 174 & 850 & & & \\
\hline & $\%$ & $43,4 \%$ & $36,1 \%$ & $20,5 \%$ & $100,0 \%$ & & & \\
\hline
\end{tabular}

Yapılan ki-kare testi sonucuna göre, öğrencilerin mezuniyet sonrasında kolay iş bulabilme düşünceleri ile öğrenim gördükleri okullar arasında anlamlı bir ilişki vardır $(p<0,05)$.

\section{Sonuç ve Tartışma}

Anket sonuçlarına göre, öğretim elemanlarından alınan hizmet kalitesi algısında üniversitelere göre anlamlı bir farklılaşma olduğu, öğrencilerin genel olarak olumlu görüş bildirdikleri söylenebilir. Öğretim elemanlarının sunmuş olduk- 
ları eğitim-öğretim hizmeti okulun toplam kalitesine doğrudan etki etmektedir. Öğretim elemanlarının sahip oldukları özelliklerin ve sundukları hizmetin, eğitim-öğretim hizmet kalitesine etki ettiği sonucu benzer çalışmalarda da test edilmiştir (Brown ve Koenig, 1993; Tütüncü ve Doğan, 2003; Saydan, 2008: Açan ve Saydan, 2009: Tayyar ve Dilşeker, 2012). Danışmandan alınan hizmet kalitesinde okullara göre farklılıklar olduğu gözlemlenmiştir. Bu sonuç Ekinci ve Burgaz'ın (2007) Hacettepe Üniversitesi öğrencileri üzerine yaptıkları çalışmanın sonucunu destekler niteliktedir.

Okulların, öğrencilerin ortak etkinlikler yapabilecekleri alanlara, bilişim-teknoloji imkânlarına sahip olmaları ve bu imkânlardan öğrencilerin kolaylıkla yararlanabilmeleri konularında öğrenciler ağırlıklı olarak kararsız, fiziki olanaklar ve bunlardan öğrencilerin kolaylıkla yararlanabilmeleri konularında da öğrenciler ağırlıklı olarak olumlu görüş bildirmişlerdir. Yapılan farklı çalışmalarda da okul fiziksel imkânlarının öğrencilerin eğitim-öğretim hizmet kalitesine yönelik görüşlerini etkilediği ortaya konulmuştur (Joseph ve Joseph, 1997; Güzel, 2006; Özçalık, 2007; Narang, 2012). Türkiye'deki TOMYO'ların fiziki konumları genel olarak değerlendirildiğinde, üniversite merkez kampüslerinin dışında kuruldukları görülmektedir. Merkez kampüsün sağladığı imkânlardan yeterince yararlanamayan öğrencilerin üniversitelerine yönelik örgütsel bağ|ılıklarının gelişmediği, bunun da öğrencilerin genel hizmet kalitesi algılarını etkilediği düşünülmektedir.

Galeeva (2016) yaptığı çalışmada, yüksek kaliteli ders içeriklerinin eğitim hizmetinin kalite kriterlerinden birisi olduğunu ortaya koymuştur. Bu çalışmada yapılan analizler sonucunda öğrencilerin dersler, ders programları ve ders içerikleri yönündeki görüşlerinin olumlu yönde olduğu görülmektedir. Ancak bu sonuç, Devebakan vd.'nin (2003) yapttkları çalışmanın "ders içerikleri öğrencilerin beklentilerini karşılamamaktadır" sonucuyla örtüşmemektedir.

Yapılan analizler sonucunda, öğrencilerin hizmet kalitesine ilişkin görüşlerinin öğrenim gördükleri bölümlere ve akademik başarı ortalamalarına göre farklılaşmadığı, cinsiyetlerine göre ise farklılaştğı belirlenmiştir. Araştırmanın bu sonucu, Sökmen'in (2011), Ay ve Koç'un (2014) ve Koç vd.'nin (2008) yaptıkları çalışmaların sonuçlarını desteklememektedir. Sökmen'in (2011) yapmış olduğu çalışmanın “öğrencilerin cinsiyetleri ile hizmet kalitesi memnuniyet boyutları arasında anlamlı bir ilişki vardır" sonucunu ise desteklemektedir. Ayrıca Sert'in (2012) yapmış olduğu çalışmanın "lisans düzeyinde turizm eğitim alan öğrencilerin memnuniyet düzeyleri ile not ortalamaları arasında bir ilişki yoktur" sonucu ile de paralellik göstermektedir.

Araştırmaya katılan öğrencilerin yaklaşık dörtte üçlük kısmı öğrenim gördüğü programı isteyerek tercih ettiğini ifade etmiştir. Ancak, Baltacı vd.'nin (2012) yapmış oldukları araştırmaya katılan Akdeniz Üniversitesi, Süleyman Demirel Üniversitesi ve Balıkesir Üniversitesi'nde ön lisans, lisans ve yüksek lisans düzeyinde turizm eğitimi alan öğrencilerin dörtte birlik kısmı öğrenim gördükleri bölümü bilerek ve isteyerek tercih ettiklerini belirtmişlerdir. Üniversiteler arasında mezuniyet sonrası eğitime devam etmek isteyen öğrenci oranı en fazla olan okulun Muğla Sıtkı Koçman Üniversitesi Marmaris TMYO olduğu belirlenmiştir. Bu okulun Türkiye'nin en gözde turizm merkezlerinden birisi olan Marmaris'te olmasından dolayı öğrencilerinin turizm sektörüne yönelik algılarının olumlu yönde etkilendiğini, turizm sektörüne karşı olumlu düşünceye sahip öğrencilerin sektörde kariyer hedeflediklerini, bunun için de eğitimlerine bir üst kademe olan lisans düzeyinde devam etmek istedikleri söylenebilir.

Yapılan analizler sonucunda, öğrencilerin mezuniyet sonrasında kolay iş bulabilme düşüncelerinin öğrenim gördükleri okullara göre farklılaştğ̆ belirlenmiştir. Mezuniyet sonrasında kolay iş bulabileceğini düşünen öğrenci oranı en düşük olan okulların Güney Doğu Anadolu'da yer alan Gaziantep Üniversitesi TOMYO, Doğu Anadolu'da yer alan İnönü Üniversitesi Kale TOIMYO ve Erzincan Üniversitesi TOMYO oldukları görülmektedir. Buna göre, okulun bulunduğu coğrafik bölgenin öğrencinin mezun olduktan sonra kolay iş bulabileceği düşüncesini etkilediği söylenebilir.

\section{6. Öneriler}

Turizm sektörünün kalifiye personel ihtiyacının karşılanmasında eğitim kurumlarına düşen görev öğrencilere kaliteli bir eğitim sunmaktır. Bunun için de sektörün önde gelen temsilcileriyle fikir alışverişi yapılarak sektörün ihtiyacına yönelik bir müfredat oluşturulması ve bu yönde bir eğitimin verilmesi gerektiği düşünülmektedir. Araştırma sonuçlarından eğitim-öğretim hizmet kalitesinin öğrenci tatminine bağlı olduğu görülmektedir. Özellikle fiziksel olanakların öğrenciler açısından en önemli kalite boyutu olduğu söylenebilir. Bu bağlamda yönetimsel hizmetin önemi de ortaya çıkmaktadır. Okul yönetimlerinin eğitim-öğretim hizmet kalitesini arttrmaya yönelik gerçekleştirebilecekleri faaliyetlerin başında okul fiziksel olanaklarını iyileştirilmesi, akademik kadronun iyi seçilmesi, ders içeriklerinin ve ders programlarının da öğrenci ihtiyaçlarına göre planlanması gelmektedir. Bu araştırma, Olcay'ın (2008) yaptığı çalışmanın, ülkemizdeki turizm eğitimine verilen önemin arttırılması, turizm eğitiminin sorunlarına etkin ve kalıcı çözümler üretilmesi gerektiği sonucunu da destekler niteliktedir.

Bu çalışmanın yapılması, Türkiye'deki TOMYO'ların eğitim-öğretim hizmet kalitesinin belirlenmesi ve mevcut eksik- 
liklerinin ortaya konulması bakımından önem arz etmektedir. Bununla beraber benzer konuda çalışma yapacak araştırmacılara, daha geniş evrende çalışarak turizm programlarını bünyesinde bulunduran diğer meslek yüksekokullarının vermiş oldukları turizm eğitim-öğretim hizmet kalitesinin araştırılması önerilebilir.

\section{Kaynakça}

Açan, B. ve Saydan, R. (2009). Öğretim Elemanlarının Akademik Kalite Özelliklerinin Değerlendirilmesi: Kafkas Üniversitesi IïF Örneği. Atatürk Üniversitesi Sosyal Bilimler Enstitüsü Dergisi, 13(2), 225-253.

Akbaba, A. (2006). Measuring Service Quality in the Hotel Industry: AStudy in a Business Hotel in Turkey. International Journal of Hospitality Management, 25, 170-192.

Akbulut, Y. (2010). Sosyal Bilimlerde SPSS Uygulamaları. İdeal Kültür Yayınclık, İstanbul.

Alp, T. (1992). Türkiye’de Turizm Eğitimin Yapısı, Uygulanan Politikalar ve Sonuçlar. Turizm Eğitimi, Turizm Bakanlı̆ı Turizm Eğitimi Genel Müdürlüğü, Yorum Basım Yayın Sanayi Ticaret Şirketi: 47, Ankara.

Altan, S., Atan, M. ve Ediz, A. (2003). SERVQUAL Analizi ile Toplam Hizmet Kalitesinin Ölçümü ve Yüksek Eğitimde Bir Uygulama. 12. Ulusal Kalite Kongresi. KalDer-Türkiye Kalite Derneği, Lütfi Kırdar Kongre ve Sergi Sarayı, İstanbul.

Ay, G. ve Koç, H. (2014). Yükseköğretimde Öğrenci Tatmin Düzeylerinin Belirlenmesi Ve Bazı Değişkenler Açısından Analizi: Büro Yönetimi Ve Yönetici Asistanlığı Programındaki Öğrenciler Üzerine Bir Uygulama. EJOVOC: Electronic Journal of Vocational Colleges, 4(3).

Baltacı, F., Üngüren, E., Avsallı, H. ve Demirel, O. N. (2012). Turizm Eğitimi Alan Öğrencilerin Eğitim Memnuniyetlerinin ve Geleceğe Yönelik Bakış Açılarının Belirlemesine Yönelik Bir Araştırma. Uluslararası Alanya İ̧̧letme Fakültesi Dergisi, Cilt: 4, Sayı: 1, Sayfa: 17-25.

Bartlett, J. E., Körtlik, J. W. and Higgins, C. C. (2001). Organizational Research: Determining Appropriate Sample Size In Survey Research. Information Technology, Learning and Performance Journal, 19 (1).

Brown, D. J. and Koenig, H. F. (1993). Applying Total Quality Management to Business Education. Journal of Education for Business, 68 (6), 325-330.

Christou, E. (1999). Hospitality Management Education In Greece: An Exploratory Study. Tourism Management, 20(6): 683-691.

Cronin, J. J. and Taylor, S. A. (1994). SERVPERF versus SERVQUAL: Reconciling Performance-Basedand Perceptions-Minus-Expectations Measurement of Service Quality. Journal of Marketing, 1994, 125-131.

Çakır, M. (2008). Vakıf Üniversitelerinde Akademik Personelin Performans Değerlendirmelerinin Eğitim Kalitesine Katkısı. Yayınlanmamış Yüksek Lisans Tezi, Gazi Üniversitesi Eğitim Bilimleri Enstitüsü, Ankara.

Çipil, B. D. (2004). Konaklama İşletmelerinde Hizmet Kalitesi Algılarının Belirlenmesi: Antalya’da 5 Yııldızlı Otel Müşterileri Üzerinde Bir Araştrrma. Yayınlanmamış Yüksek Lisans Tezi Osmangazi Üniversitesi, Sosyal Bilimler Enstitüsü, Eskişehir.

Devebakan, N., Koçdor. H., Musal, B. ve Güner, G. (2003). Dokuz Eylül Üniversitesi Sağlık Bilimleri Enstitüsünde Lisansüstü Eğitimin Kalitesinin Arttrııması Kapsamında Öğrencilerin Eğitime llişkin Görüşlerinin Değerlendirilmesi. Dokuz Ey/ül Üniversitesi Sosyal Bilimler Enstitüsü Dergisi, cilt: 5, sayl: 2.

Duman, T., Tepeci, M. ve Unur, K. (2014). Mersin'de Yükseköğretim ve Orta Öğretim Düzeyinde Turizm Eğitimi Almakta Olan Öğrencilerin Sektörün Çalışma Koşullarını Algılamaları ve Sektörde Çalışma Isteklerinin Karşılaştırmalı Analizi. Anatolia: Turizm Araştırmaları Dergisi Cilt 17, Sayı 1, 51-69.

Ekinci, C. E. ve Burgaz, B. (2007). Hacettepe Üniversitesi Öğrencilerinin Bazı Akademik Hizmetlere ilişkin Beklenti ve Memnuniyet Düzeyleri. Hacettepe Üniversitesi Eğitim Fakültesi Dergisi (H. U. Journal of Education) 33, 120-134.

Ergün, B. (2013). Lisans Düzeyinde Turizm Eğitimi Verilen Kurumlardaki Hizmet Kalitesine Yönelik Bir Değerlendirme. Yayınlanmamış Yüksek Lisans Tezi, Afyon Kocatepe Üniversitesi Sosyal Bilimler Enstitüsü, Afyonkarahisar.

Galeeva, R. B. (2016). SERVQUAL Application and Adaptation For Educational Service Quality Assessments In Russian Higher Education. Quality Assurance in Education Vol. 24 No. 3, pp. 329-348.

Garwe, E. C. (2015). Student Voice and Quality Enhancement In Higher Education. Journal of Applied Research in Higher Education, Vol. 7 No. 2, pp. 385-399.

Gelmez, M. (2016). Sağlıkta Hizmet Kalitesinin Değerlendirilmesi: Bir Araştırma Hastanesi Uygulaması. Yayınlanmamış Yüksek Lisans Tezi, Ankara Üniversitesi Sağlık Bilimleri Enstitüsü, Ankara.

Gülenç, i. F. ve Talih, D. (2011). Eğitim Sektöründe Hizmet Kalitesi Algılamalarına İlişkin Yabancı Dil Kurumlarında Bir Araştrrma. Trakya Üniversitesi Sosyal Bilimler Dergisi, Cilt 13 Sayı 2 (261-284).

Gürbüz, S. \& Şahin, F. (2015). Sosyal Bilimlerde Araştırma Yöntemleri. Seçkin Yayıncılık, 2.Baskı, Ankara.

Güzel, N. G. (2006). Yükseköğretimde Turizm Eğitimi ve Hizmet Kalitesi. Gazi Üniversitesi Eğitimi Bilimleri Enstitüsü, Doktora Tezi, Ankara.

Grönross, C. (1990). Service Management and Marketing: Managing the Moments of Truthin Service Marketing. Toronto: Lexington Books. Halai, N. (2012). Quality of Private Universities In Pakistan. International Journal of Educational Management Vol. 27 No. 7, pp. 775-786.

Hacıoğlu, N. (1992). Yükseköğretimde Mesleki Turizm Eğitimi Geliştirme Perspektifleri. Turizm Eğitimi, Ankara, Turizm Bakanlığı Turizm Eğitimi Genel Müdürlüğü, Yorum Basın Yayın San. Ltd. Şti.: 92.

Joseph, M. and Joseph, B. (1997). Service Quality In Education: A Student Perspective. Quality Assurance in Education, Volume 5, Number 1, pp. 15-21.

Koç, H., Arslantürk, Y. ve Arslan, S. (2008). Yüksek Öğretimde Öğrenci Tatmin Düzeyler ile Başarı Ortalamaları Arasındaki Illişki: Hazırlık Sınıfı Öğrencileri Üzerinde Bir Uygulama. Journal Of Commerce, (1), 57.

Narang, R. (2012). How Do Management Students Perceive The Quality of Education In Public Institutions? Quality Assurance in Education Vol. 20 No. 4, 2012 pp. 357-371. 
Olcay, A. (2008). Türk Turizminde Eğitimin Önemi. Gaziantep Üniversitesi Sosyal Bilimler Dergisi, 7 (2), 383-390.

Olcay, A. ve Düzgün, M. (2015). Mesleki Ve Teknik Anadolu Liselerinde Turizm Eğitimi Almakta Olan Öğrencilerin Eğitim Memnuniyetlerinin Belirlenmesi. Uluslararası Hakemli Beşeri ve Akademik Bilimler Dergisi, Nisan/Mayıs/Haziran ilkbahar Yaz dönemi, Cilt: 4, Sayı: 12.

Olcay, A., Sürme, M., Düzgün, M. ve Cinpolat, M. (2016). Turizm Ön Lisans Öğrencilerinin Eğitimlerine İlişkin Beklentileri. Giresun Üniversitesi Sosyal Bilimler Enstitüsü, Karadeniz Sosyal Bilimler Dergisi, Sonbahar, Sayı: 15, S.S.321-338.

Özçalık, F. (2007). Yükseköğretimde Eğitim Hizmet Kalitesinin Ölçümüne Yönelik Örnek Bir Uygulama. Yayınlanmamış Yüksek Lisans Tezi, Gazi Üniversitesi Sosyal Bilimler Enstitüsü, Ankara.

Özgül, E. ve Devebakan, N. (2005). Üniversitelerde Servqual Tekniği Ile Algılanan Hizmet Kalitesinin Ölçülmesine Yönelik Karşılaştırmalı Bir Araştırma. Yönetim Bilimleri Dergisi (3:2).

Parasuraman, A., Zeithaml, V. A. ve Berry, L. L. (1985). A Conceptual Model of Service Quality And Its Implications For Future Research. The Journal of Marketing (1985): 41-50.

Parasuraman, A., Zeithaml, V. A. and Berry, L. L. (1988). SERVQUAL: A Multiple-Item Scale for Measuring Customer Perceptions of Service Quality. Journal of Retailing. 64 (1), 12-43.

Pehlivan, R. (2008). Lisans Düzeyinde Turizm Eğitimi Almakta Olan Öğrencilerin Sektör ile Illgili Tutumlarının Mezuniyet Sonrası Kariyer Seçimine Etkisi. Yayınlanmamış Yüksek Lisans Tezi, Adnan Menderes Üniversitesi, Sosyal Bilimler Enstitüsü, Aydın.

Pelit, E. ve Güçer, E. (2006). Turizm Alanında Öğretmenlik Eğitimi Alan Öğrencilerin Turizm İşletmelerinde Yaptıkları Stajları Değerlendirmeleri Üzerine Bir Araştırma. Ticaret ve Turizm Eğitim Fakültesi Dergisi 1: 139-168.

Petruzzellis, L., D’Uggento, A. M. and Romanazzi, S. (2006). Student Satisfaction and Quality of Service In Italian Universities. Managing Service Quality, Vol. 16 No. 4, 2006pp. 349-364

Saydan, R. (2008). Üniversite Öğrencilerinin Öğretim Elemanlarından Kalite Beklentileri: Yüzüncü Yıl Üniversitesi İ̈BF Örneği. Gazi Üniversitesi Iktisadi ve Idari Bilimler Fakültesi Dergisi 10(1), 63-79.

Sert, S. (2012). Lisans Düzeyinde Turizm Eğitim Alan Öğrencilerin Memnuniyet Düzeyleri ile Not Ortalamaları Arasındaki Ilişki. Turizm Eğitim Konferansı, s.s.17-19, Ankara.

Seymen, O. A. (2002). Turizm İşletmelerinde Oryantasyon Eğitiminin İnsan Kaynakları Yönetimi Açısından Önemi ve Buna Yönelik Program Modelinin Oluşturulması. Anatolia Turizm Araştırmaları Dergisi, 13(1), 15-25.

Sezgin, O. M. (2001). Genel Turizm ve Turizm Mevzuatt. Ankara, Detay Yayınclık: 135.

Sökmen, A. (2011). Öğrenci Memnuniyetine Yönelik Ankara'daki Bir Meslek Yüksekokulunda Araştırma. İşletme Araştırmaları Dergisi 3/4, 66-79.

Şahin, A. E. (2009). Eğitim Fakültesinde Hizmet Kalitesinin Eğitim Fakültesi Öğrenci Memnuniyet Ölçeği (EF-ÖMÖ) İle Değerlendirilmesi. Hacettepe Üniversitesi Eğitim Fakültesi Dergisi, 37, 106-122).

Şahin, İ. ve Fındık, T. (2008). Türkiye’de Mesleki ve Teknik Eğitim: Mevcut Durum, Sorunlar ve Çözüm Önerileri. Türkiye Sosyal Araştırmalar Dergisi, Sayı: 12 (3), Sayfa: 65-86.

Tayyar, N. ve Dilşeker, F. (2012). Devlet ve Vakıf Üniversitelerinde Hizmet Kalitesi ve İmajın Öğrenci Memnuniyetine Etkisi. Muğla Üniversitesi Sosyal Bilimler Enstitüsü Dergisi Sayı 28, 184-203.

Telbalkan, M. (2015). Ön Lisans Düzeyinde Turizm Eğitimindeki Staj Uygulamasına Yönelik Öğrencilerin Bakışları: Ondokuz Mayıs Üniversitesi'nde Bir Uygulama. Electronic Journal of Vocational Colleges- Aralık 2015 4. UMYOS Özel Sayısı.

Tezsürücü, D. ve Bursalıoğlu, S. A. (2013). Yükseköğretimde Değişim: Kalite Arayışları. Kahramanmaraş Sütçü Imam Üniversitesi Sosyal Bilimler Dergisi, 10(2).

Tsang, N. and Qu, H. (2000). Service Quality in China's Hotel Industry: A Perspective from Tourists and Hotel Managers. International Journal of Contemporary Hospitality Management, 12(5), 316-326.

Tufan, M., Mırrak, Ş. ve Çelik, D. (2009). Mesleki Eğitimde Toplam Kalite Yönetimi ve Model Önerisi. Journal of Azerbaijani Studies, sayı: 12, s.s: $27-40$.

Tütüncü, Ö. ve Doğan, Ö. P. (2003). Müşteri Tatmini Kapsamında Öğrenci Memnuniyetinin Ölçülmesi ve Dokuz Eylül Üniversitesi, Sosyal Bilimler Enstitüsü Uygulaması. Dokuz Eylül Üniversitesi Sosyal Bilimler Enstitüsü Dergisi, Cilt: 5, Sayı: 4, 130-151.

Ünlüönen, K. (2000). Turizm İşletmeciliği Öğretmenlik Programlarının Öğrenci Beklentileri ve Algılamaları Açısından Değerlendirilmesi. Gazi Üniversitesi Ticaret ve Turizm Eğitim Fakültesi Dergisi, 3, 218-238.

Yılmaz, İ. (2007). Otel İşletmelerinde Hizmet Kalitesinin Müşteriler ve Yöneticiler Açısından Ölçülmesi. Dokuz Eylül Üniversitesi Sosyal Bilimler Enstitüsü, Izmir.

Yılmaz, V., Filiz, Z. ve Yaprak, B. (2007). Servqual Yöntemiyle Yükseköğretimde Hizmet Kalitesinin Ölçülmesi. Anadolu Üniversitesi Sosyal Bilimler Dergisi, Cilt/Nol.:7-Sayı/No: 1 : 299-316.

Yükseköğretim Kanunu, (1981), Md.3.

\section{Elektronik Kaynaklar}

Yüksek Öğretim Kurulu, URL: [https://yok.gov.tr] Erişim Tarihi: 15 Nisan 2017

Yüksek Öğretim Kurulu Yüksek Öğretim Program Atlası, URL: [https://yokatlas.yok.gov.tr/onlisans-program.php?b=30109] Erişim Tarihi: 20 Nisan 2017

Yükseköğretim Kurulu Yükseköğretim Bilgi Yönetim Sistemi, URL: [https://istatistik.yok.gov.tr/] Erişim Tarihi: 10 Nisan.2017

Ölçme, Seçme ve Yerleştirme Merkezi (ÖSYM) 2016 ÖsYS Yüksek Öğretim Programları ve Kontenjanları Klavuzu, URL :[http://www.osym. gov.tr/TR,12454/2016-osys-yuksekogretim-programlari-ve-kontenjanlari-kilavuzu.html] Erişim Tarihi: 24 Nisan 2017

| Kastamonu Eğitim Dergisi, 27(2), 2019| 